\title{
Microstructure Theory and the Foreign Exchange Market
}

A GROWING BODY OF theoretical literature, known as the study of securities market microstructure, deals with the behavior of participants in securities markets and with the effects of information and institutional rules on the economic performance of those markets. These institu. tional factors may arise from technology, tradition or regulation. Microstructure and its impact are important, because of the vast amounts of wealth which pass through securities markets including the foreign exchange market every day.

Microstructure is of interest to students of the foreign exchange market: microstructural analyses of other markets have yielded insight into traders' behavior and the effect of various institutional arrangements. Conversely, the foreign exchange market is also of special interest to students of microstructure, because it combines two very different arrangements for matching buyers and sellers - bank dealers trade with one another both directly and through foreign exchange brokers. ${ }^{1}$

Standard models of exchange-rate determina* tion concentrate on relatively long-run aspects, such as purchasing power parity. While microstructure theory cannot address these issues directly, it can illuminate a more narrowly focused array of institutional concerns, such as price information, the matching of buyers and sellers, and optimal dealer pricing policies. Despite the substantial literature on microstructure, little attention has been paid to the particular microstructure of the foreign exchange market. ${ }^{2}$
iSimilar arrangements exisi for other securities-for example, the tederal funds market and the secondary market for Treasury securities-but these too have been relatively neglected in the literature.

2The shaded insert on the opposite page provides a context in which the microstructural approach can be compared with more traditional approaches to market efficiency.

Following some early articles by Demsetz (1968), Tinic (1972) and Tinic and West (1972), Garman (1976) performed the crucial task of defining market microstructure as an independent area of the literature, thus focusing the debate. Since then, market microstructure has burgeoned, led by Cohen, Maier, Schwartz and Whitcomb (1978a, 1978b, 1981, 1983), Aminud and Mendelson (1980, 1986. 1988), Stoll $(1978,1985,1989)$ and Ho and Stoll $(1980$, 1981). See also Beja and Hakansson (1977), Cohen, Hawawini, Maier, Schwartz and Whitcomb (1980), Cohen, Maier, Ness, Okuda, Schwartz and Whitcomb (1977). Amihud, Ho, and Schwartz (1985), Schreiber and Schwartz (1986), Schwartz (1988) and Cohen and Schwartz (1989).
Cohen, Maier, Schwartz and Whitcomb $(1979,1986)$ and Stoll (1985) have surveyed the microstructure literature.

In addition to the earfy note by Allen (1977), very recently there have appeared some microstructural studies of the foreign exchange market: Bossaerts and Hillion (1991), Lyons (1991), Rai (1991) and Flood (1991). There is also an empirical literature measuring the determinants of the bid-ask spread in the foreign exchange market. See Black (1989), Wei (1991) and Glassman (1987) as well as the references therein. Because the focus of this article is on microstructure theory, such empirical studies receive little attention here.

Finally, although a consideration of the results of laborato. ry experiments would expand the scope of this paper to unwieldy dimensions, their role in establishing the sensitivity of market behavior to institutional factors must at least be acknowledged; see Plott $(1982,1991)$ for an introduction. 


\section{Price Efficiency in a Heterogeneous Marketplace}

Implicit in most mierostructural models is a presumpiton that participants il any gwen harket are heterugenemis, that is that hey differ in certain key determinants of econom 10 heliavior: information, belicss breferences. and weallh. Alhough his assumption con: simes thle atlention in the mierestmictute: therature - if is taken lor granled it is valuable to discuss it in the nore familiar heoretieal context of namer eflictency.

The standard definition of prited efferener is. $f(p) I$. loint distribution over rutare prices $f(p)$ as sessed by the monolithic narket for a repres. sentative agent in that marketl and made conditional on the current information, 1 . avalable to the market is equal to the "Tue" jomt distribution $\mathrm{I}^{\prime}(\mathrm{p})$. made conditiona on all cument information, 1 , renghly speak ing. the marker somts things out as accurately as jossible?

This approach hreaks down in a micro. strictaral analysis. I Tirst the simplifying as: sumption of homogencous participants is ahandoned Alhough if is widely recoggnized that investors do ner show the homogenety of beliefs whinh charactemize our theories? the benents of realism it. . the heterogemeity assimption are ofter antwelghed by ather. crilema le g. testability tractability ete t: $1 \mathrm{~m}$. phastzing testablity Ross offers a staniard rejomder, namely that sinee a single ex post distribition of returins is observed by all. over line one would not expect to observe svstematic and persistent differences this is a tational expectations argument, which de. pends cricially on the stationarity of the retums distrilution and which gnores he ef fect of differences in opinions and beliefs: which go beyond ditterences in information.

158 rama $(1976)$, chapter 5 , for the tefinitive presen tation:

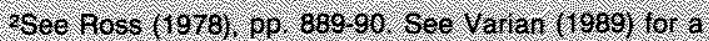
nore thorough leviow of lie theoretical issues nvoved in 1 e helerogeneity assumption.
In general hen at the level of tetai nuwlved in nicrostruchual studies, the homogeneity. assumption is not an ex cusable that in a lomingenoous namlet why - let hlone low. woull anyone wade?

More tundanienlaty, the notion or a ther ircer nust he questioned. In the canilext of

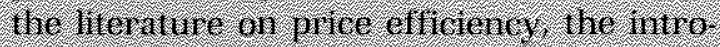
duction of a : imie" distribution as a theorettcal conceit leads to joint testing problems as

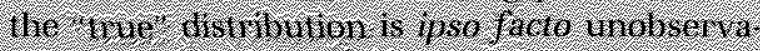
ble: Nore findamentally pesiting a true? distribution contuses the cham of eatisaticy: it presnimes liat furure prices are drann from some exogenous probability distribuitum and that investor behtuior is concernet with ac curatey estimaing that dismibution.

in lact, huestor behavion: in the narket place determines the distribition of future prices not the ollier way around, This tact in no way depenis on the illimate basis or noivation for investor behavior in an explicit nodel of price discovery. the assertion of an ex ante exogenous equilibrium price is nean ingless. is sehreher and sthwarts pul it. the fact that secuint inalysts assess the value of a stocl for heir own portfolios does h6l imply that they undertake d treasure hum lo ind some golden number which one meht eall an inrinsic valie:s 10 stim the standard theory or chicleit markets is 11. suited to the nodeling of orice disconery in comparing observed prices to an imputed true: distribution, studies of market efficien cy rgnore more mmediate concerns - for ex: ample how vell the institutional strueture transunit intormation wllether arbitrage op. portumilies bectr, and how wall the narket allocates assets among investors. These con cems a e thr foeus of mierostructural andy sis.

See schie ber ard schwars (1985), o 22 
This paper examines the extant literature on market microstructure to determine how it might be applied to the foreign exchange market.

The paper begins with a brief description of the foreign exchange market. Aspects of the literature concerned with institutional details are addressed second, noting how such details can affect the performance of the market. Next, the literature dealing with behavioral details, especially the communication and interpretation of price information, is considered. Finally, the interaction of institutional and behavioral factors, notably the bid-ask spread, is discussed.

\section{INSTITUTIONAL BASICS OF THE FORPIGN EXCHANGE MATKET}

The foreign exchange market is the international market in which buyers and sellers of currencies "meet," It is largely decentralized: the participants (classified as market-makers, brokers and customers) are physically separated from one another; they communicate via telephone, telex and computer network. Trading volume is large, estimated at $\$ 128.9$ billion for the U.S. market in April 1989. Most of this trading was between bank market-makers. ${ }^{*}$

The market is dominated by the market-makers at commercial and investment banks, who trade currencies with each other both directly and through foreign exchange brokers (see figure 1)." Market-makers, as the name suggests, "make a market" in one or more currencies by providing bid and ask prices upon demand. A broker ar. ranges trades by keeping a "book" of marketmaker's limit orders - that is, orders to buy (alternatively, to sell) a specified quantity of foreign currency at a specified price - from which he quotes the best bid and ask orders upon request. The best bid and ask quotes on a broker's book are together called the broker's "inside spread." The other participants in the market are the customers of the market-making banks, who generally use the market to complete transactions in international trade, and central banks, who may enter the market to move ex-

3For more thorough descriptions of the workings of the for" eign exchange market, see Burnham (1991), Chrystal (1984), Kubarych (1983) and Riehl and Rodriguez (1983).

4See Federal Reserve Bank of New York (1989a) and Bank for Intemational Settlements (BIS) (1990). Extending this figure over 251 trading days per year, this implies a trad. ing volume of roughly $\$ 32$ trillion for all of 1989 . Volume

\section{Figure 1 \\ Spot Market Volume by \\ Transactor (4/89)}

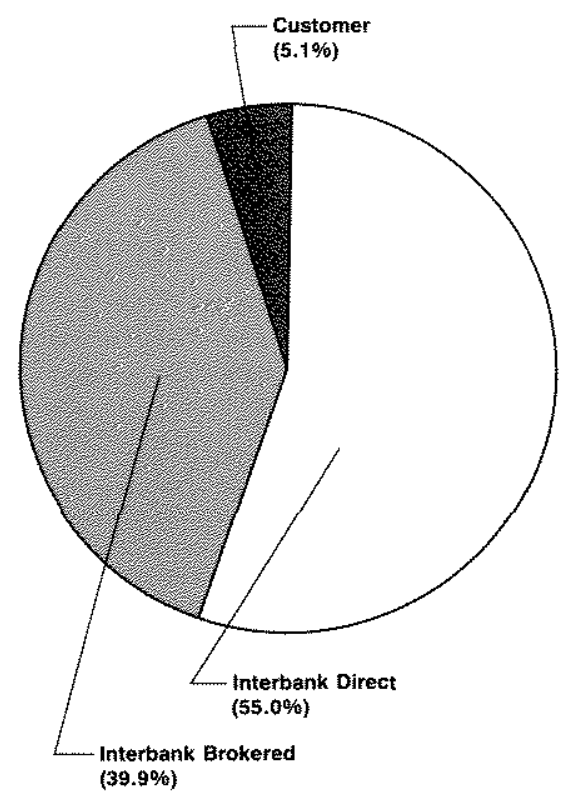

change rates or simply to complete their own international transactions. Market-makers may trade for their own account - that is, they may maintain a long or short position in a foreign currency - and require significant capitalization for that purpose. Brokers do not contact cus. tomers and do not deal on their own account; instead, they profit by charging a fee for the service of bringing market-makers together.

The mechanics of trading differ substantially between brokered transactions and direct deals. In the direct market, banks contact each other. The bank receiving a call acts as a market-maker for the currency in question, providing a twoway quote (bid and ask) for the bank placing the call. A direct deal might go as follows:

\section{Mongobank: "Mongobank with a dollar-mark please?"}

(Mongobank requests a spot market quote for U.S. dollars (USD) against German marks (DEM).)

has roughly doubled every three years for the past decade.

5Federal Reserve Bank of New York (1989a) ists 162 market-making institutions (148 are commercial banks) and 14 brokers; an earlier study, Federal Reserve Bank of New York (1980), lists 90 market-making banks and 11 brokers. 


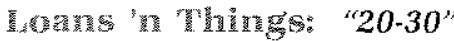

(Loans $n$ ' Things will buy dollars at 2.1020

DEM/USD and sell dollars at 2.1030 DEM/USD

-the 2.10 part of the quote is understood.)

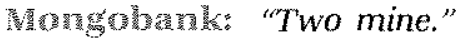

(Mongobank buys $\$ 2,000,000$ for DEM

$4,206,000$ at $2.1030 \mathrm{DEM} / \mathrm{USD}$, for payment

two business days later. The quantity traded is usually one of a handful of "customary amounts.")

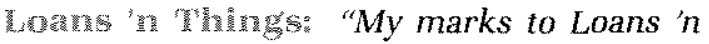 Things Frankfurt."}

(Loans $n$ ' Things requests that payment of marks be made to their account at their Frankfurt branch. Payment will likely be made via SWIFT.j6

\section{Whagahornk: "My dollars to Mongobank New York."}

(Mongobank requests that payment of dollars be made to them in New York. Payment will most likely be made via CHIPS.) ${ }^{7}$

Spot transactions are made for "value date" (payment date) two business days later to allow settlement arrangements to be made with correspondents or branches in other time zones. This period is extended when a holiday intervenes in one of the countries involved. Payment occurs in a currency's home country.

The other method of interbank trading is brokered transactions. Brokers collect limit orders from bank market-makers. A limit order is an offer to buy (alternatively to sell) a specified quantity at a specified price. Limit orders remain with the broker until withdrawn by the market-maker.

The advantages of brokered trading include the rapid dissemination of orders to other market-makers, anonymity in quoting, and the freedom not to quote to other market-makers on a reciprocal basis, which can be required in the direct market. Anonymity allows the quoting bank to conceal its identity and thus its intentions; in also requires that the broker know who is an acceptable counterparty for whom. Limit orders are also provided in part as a courtesy to the brokers as part of an ongoing business relationship that makes the market more liquid. Because his limit order is often a market-maker's first indication of general price shift, Brooks likens the posting of an order with a broker "to sticking out the chin so as to be acquainted with the moment that the fight starts." Schwartz points out that posting a limit order extends a free option to other traders. ${ }^{9}$

A market-maker who calls a broker for a quote gets the broker's inside spread, along with the quantities of the limit orders. A typical call to a broker might proceed as follows:

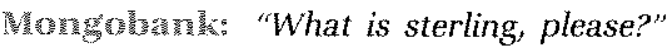
(Mongobank requests the spot quote for U.S. dollars against British pounds (GBP).)

Tommesterse "I deal 40.42, one by two." (Fonmeister Brokerage has quotes to buy $£ 1,000,000$ at $1.7440 \mathrm{USD} / \mathrm{GBP}$, and to sell $£ 2,000,000$ at $1.7442 \mathrm{USD} / \mathrm{GBP}$ )

Wongobank: "I sell one at 40, to whom?" (Mongobank hits the bid for the quantity stated. Mongobank could have requested a different amount, which would have required additional confirmation from the bid. ding bank.)

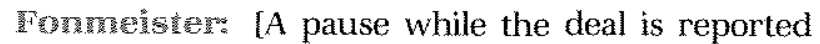
to and confirmed by Loans ' $n$ Things] "Loans in Things London." (Fonmeister confirms the deal and reports the counterparty to Mongobank. Payment arrangements will be made and confirmed separately by the respective back offices. The broker's back office will also confirm the trade with the banks.)

Value dates and payment arrangements are the same as in the direct dealing case. In addition to the payment to the counterparty bank, the banks involved share the brokerage fee. These fees are negotiable in the United States. They are also quite low: roughly $\$ 20$ per million dollars transacted. ${ }^{10}$
GThe Society for Worldwide Interbank Financial Telecommunication (SWIFT) is an efectronic message network. In this case, if conveys a standardized payment order to a German branch or correspondent bank, which, in turn, effects the payment as a local interbank transfer in Frankfurt.

The Clearing House for Interbank Payments System (CHIPS) is a private interbank payments system in New York City. see Brooks (1985), p. 25

SSee Schwartz (1988), p. 239

10See Burnham (1991), p. 141, note 16 , and Kutarych (1983), p. 14. 
The final category of participants in the for. eign exchange market is the corporate customers of the market-making banks. Customers deal only with the market-makers. They never go through brokers, who cannot adequately monitor their creditworthiness. Typically, a customer transacts with a bank with which it already has a well-established relationship, so that corporate creditworthiness is not a concern for the bank's foreign exchange desk, and trustworthiness is not an issue for the customer. The mechanics of customer trading are similar to those of direct dealing between market-makers. A customer requests a quote, and the bank makes a two-way market; the customer then decides to buy, sell or pass. The chief difference between this and an interbank relationship is that the customer is not expected ever to reciprocate by making a market.

Participants in the foreign exchange market also deal for future value dates. Such dealing composes the forward markets. Active forward markets exist for a few heavily traded currencies and for several time intervals corresponding to actively dealt maturities in the money market. Markets can also be requested and made for other ma* turities, however. Since the foreign exchange market is unregulated, standard contract specifications are matters of tradition and con" venience, and they can be modified by the transacting agents.

Forward transactions generally occur in two different ways: outright and swap. An outright forward transaction is what the name implies, a contract for an exchange of currencies at some future value date. "Outrights" generally occur only between market-making banks and their commercial clients. The interbank market for outrights is very small, because outright trading implies an exchange rate risk until maturity of the contract. When outrights are concluded for a commercial client, they are usually hedged immediately by swapping the forward position to spot. This removes the exchange rate risk and leaves only interest rate risk.

A swap is simply a combination of two simultaneous trades: an outright forward contract and an opposing spot deal. For example, a bank might "swap in" six-month yen by simultaneously buying spot yen and selling six-month forward

\section{Figure 2 Market-Maker Volume by Type (4/89)}

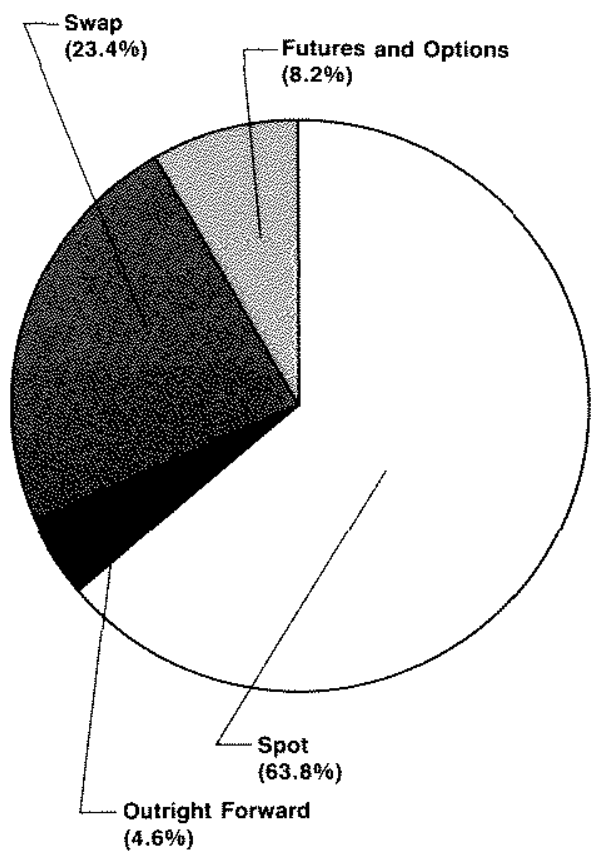

yen. Such a swap might be used to hedge an outright purchase of six-month yen from a bank customer." In effect, the swapping bank is borrowing yen for the six months of the outright deal. The foreign exchange market-maker swaps in yen - rather than simply borrow yen on a time deposit - because banks maintain separate foreign exchange and money market accounts for administrative reasons. Swapping is generally the preferred means of forward dealing (see figures 2 and 3 ).

In practice, the vast majority of foreign exchange transactions involve the U.S. dollar and some other currency. The magnitude of U.S. foreign trade and investment flows implies that, for almost any other currency, the bilateral dollar exchange markets will have the largest volume. Consequently, the dollar markets are the most liquid. The possibility of triangular arbitrage enforces the law of one price for the cross rates. The upshot is that liquidity considerations outweigh transaction costs. A German wanting

\footnotetext{
11Hedging an outright purchase of currency with an opposing swap deal still leaves an open spot purchase of the currency. This can be easily covered in the spot market.
} 


\section{Figure 3 Broker Volume by Type (4/89)}

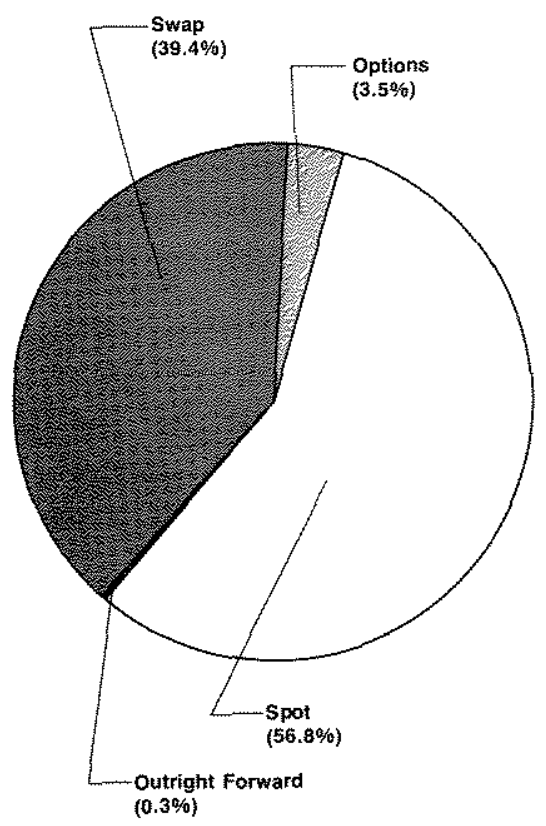

pounds, for example, will typically convert marks to dollars and then dollars to pounds, rather than trading marks for pounds directly. Though this is especially true in the American market, it holds for foreign markets as well.

\section{CLASSIIVING MAPERTS}

The microstructure literature is by nature market-specific, and much of it concerns U. S. equity markets. This specificity has the advantage of realism, but it makes the immediate applicability of some microstructural models to the foreign exchange market questionable. The first task is to define some basic microstructural concepts, identifying where the foreign exchange market fits into the context they provide. Such a taxonomy is important, because one of the fundamental lessons of the microstructure lit- erature is that institutional differences can affect the efficiency of prieing and allocation.

As described above, the foreign exchange market combines two disparate auction structures for the same commodity: the interbank direct market and the brokered market. Defying a naive application of institutional Darwinism, whereby only the fitter of the two systems would survive, these trading methods appear to coexist comfortably. ${ }^{12}$ The direct market can be classified as a decentralized, continuous, openbid, double-auction market. The brokered market is a quasi-centralized, continuous, limit-book, single-auction market. The meanings of these classifications are explained below.

\section{Centralization}

In a centralized market, "trades are carried out at publicly announced prices and all traders have access to the same trading opportunities." In a decentralized market, in contrast, "prices are quoted and transactions are concluded in private meetings among agents." ${ }^{13}$ A New York Stock Exchange's (NYSE) specialist system is a centralized market; the interbank direct market for foreign exchange is a decentralized one.

The distinction between centralized and decentralized markets might seem to provide a neat dichotomy of possible market structures. The multiplicity of brokers in the foreign exchange market violates this simple taxonomy, however. Each foreign exchange broker accumulates a subset of market-makers' limit orders. This network of "brokerage nodes" is as different from a fully centralized system as it is from a fully decentralized one. This arrangement is labeled here as "quasi-centralized."

Most microstructural studies have confined themselves to centralized markets, especially the NYSE's specialist system and the National Association of Securities Dealers Automated Quotation (NASDAQ) System on the over-the-counter (OTC) market. ${ }^{14}$ Although there are a number of important decentralized markets, including the interbank direct foreign exchange market, rela-
12A Similar situation obtains on the New York Stock Exchange, where specialists act as either brokers or marketmakers, depending on the level of activity in the market.

${ }^{13}$ See Wolinsky (1990), p. 1. He goes on to analyze theoretcally the difference in the price discovery process between centralized and decentralized markets. Schwartz (1988), pp. 426-35, refers to centralization as "spatial consolidation."
14For models of specialist systems, see Demsetz (1968), Tin- ic (1972), Garman (1976), Bradfield (1979), Amihud and Mendelson (1980), Conroy and Winkler (1981), Glosten and Milgrom (1985) and Sirri (1989). For studies of the OTC market, see Tinic and West (1972). Benston and Hagerman (1974), Ho and Macris (1985) and Stoll (1989),


tively few studies have focused on the impact of decentralization.

There is some evidence that differences in the degree of centralization between various markets cause differences in market performance. Garbade, in studying the largely decentralized Treasury securities market, concludes that because brokerage tends to centralize trading and price information, it "uses time more efficiently" "eliminates the most important arbitrages," and benefits dealers by ensuring that orders are executed according to price priority. ${ }^{13}$

The efficiency gains of centralized price information may imply economies of scale and, thus, a natural monopoly for brokers in securities markets. This is entirely consistent with the textbook presentation of the relatively greater operational efficiency of centralized markets. ${ }^{16}$ Thus, the fact that a number of brokers service the foreign exchange market seems to represent a discrepancy between theory and reality. Broker's do communicate among themselves, however, to eliminate the possibility of arbitrage between limit order books. While this helps explain the multiplicity of brokers, it does not fully resolve the issue of decentralization in the interbank direct market.

\section{Temporal Consolldation}

The distinction between a continuous market and a call market involves what Schwartz refers to as the degree of "temporal consolidation." In a call market, trading occurs at pre-appointed times (the "calls"), with arriving transaction orders detained until the next call for execution. In continuous markets, like the foreign exchange market, trading occurs at its own pace, and transaction orders are processed as they arrive. A range of intermediate arrangements falls between these two extremes.

\footnotetext{
15See Garbade (1978), p. 497
}

16 The textbook argument counts tips to market. Briefly, if there are $N$ traders, then a total of $N$ trips to a central marketplace are required for each to haggle with everyone else; to pair them bilaterally requires a total of $\mathrm{N}(\mathrm{N}-1) / 2$ trips. 奉 trips are costly, then certratization is more efficient.

17See Schwartz (1988), pp. 435-47. Garman (1976), pp. 257 58, also describes continuous and call markets; he relers to these as asynchronous and synchronous markets, respectively.

18See Hahn (1984), Negishi (1962), Beja and Hakansson (1977), as well as the references therein.

${ }^{19} \mathrm{~A}$ continuous market cannot be viewed as a continuum of infinitesimally lived call markets. Clearing supply and de-
Most microeconomic models assume call markets. In a Walrasian tâtonnement model, for example, an auctioneer calls out a series of prices and receives buy and sell orders at each price. When a price is found for which the quantities supplied and demanded are equal, all transactions are consummated at that price. Interestingly enough, Walras based this price discovery model on the mechanics of the Paris Bourse.

Temporal consolidation can affect the performance of a market. Theoretical work indicates how continuous trading can alter allocations, the process of price discovery and even the ultimate equilibrium price. ${ }^{18}$ The basic thrust of these arguments is that, with continuous trading, earlier transactions satisfy some consumers and producers, causing shifts in supply and demand that affect prices for later transactions. As a result, the Paretoefficiency characteristic of Walrasian equilibria does not necessarily obtain in continuous markets. ${ }^{19}$

On the other hand, the periodic batching of orders that occurs in a call market also has disadvantages. The difference in time between order placement and execution can impose real costs on investors. A recurring argument in the literature is the willingness of investor's to pay more - a liquidity premium - for the ability to trade immediately. Similarly, periodic calls delay any information conveyed by prices until the time of the call, introducing price uncertainty in the period between the calls.

In sum, a trade-off exists between the aliocational efficiency of the nearly Walrasian call market system and the informational efficiency and immediacy of the continuous market system. ${ }^{21}$ It is not clear whether the microstructure of the foreign exchange market represents a globally optimal balance of these relative ad.

mand in each such call market would require an infinite trading volume over the course of a day. Cohen and Schwartz (1989) fecommend an electronic order-routing system for the stock exchanges, to facilitate the placement and revision of orders. This would encourage additional trading volume, making more frequent calls feasible.

zaSee Stoll (1985), p. 72, and especially Schwartz (1988), pp. 442-53, for a more thorough exposition of the pros and cons of temporal consolidation. Intermediate arrangements are also possible. For example. Schwartz argues that many of the problems caused by infrequent batching in a call market might be overcome by expanding access to the market with comptter technology, whereby the increased number of traders would allow for more frequent calls. 
vantages. A persistent deviation from optimality might be explained, for example, by arguing that the allocational benefits of a call market system are a public good.

\section{Communication of Prices}

The terms "open-bid" and "limit-book" refer to ways in which price information is communicated. In an open-bid market - the open outcry system on the futures exchanges, for example - offers to buy or sell at a specified price are announced to all agents in the market. At the opposite extreme, in a sealed-bid market, orders are known only to the entity placing the order and perhaps to a disinterested auctioneer.

Direct trading in foreign exchange approximates the standard open-bid structure. The salient difference between the foreign exchange market and the standard arrangement is the bilateral pairing of participants in the foreign exchange market. In principle, any participant can contact a market-maker at any time for a price quote. The bilateral nature of such contacts and the time consumed by each contact together imply, however, that all participants cannot be simultaneously informed of the current quotes of a market-maker. This practical constraint on the dissemination of price information is significant: it introduces the possibility of genuine arbitrage, that is, of finding two market-makers whose current bid-ask spreads do not overlap.

The limit order book, which is used by both foreign exchange brokers and stock exchange specialists, is another intermediate form of price communication. Although it would be possible in principle for foreign exchange brokerage books to be fully open for public inspection, in practice only certain orders - namely, the best bid and ask on each book - are revealed to market-makers, while the others remain concealed. As in the direct market, market-makers must contact brokers bilaterally to get these "in. side spreads." Knowledge of the concealed limit orders would be of speculative value to marketmakers, because an imbalanced book suggests that large future price movements are more likely in one direction than the other.

More generally, price communication is intimately related to the role of market-makers as providers of "predictable immediacy." ${ }^{121}$ Market participants are willing to pay a liquidity premium, usually embedded in a market-maker's spread, for the reduction in search costs implied by constant access to a counterparty. The costs of "finding" the other side of a transaction can be further broken down into the liquidity concession, the cost of communicating the information and the cost of waiting for potential counterparties to respond. ${ }^{22}$ Other things equal, an efficient system of price communication is one that minimizes such transaction costs. While the communication of price information is a central function of securities markets, the fact that the systems of price communication in the foreign exchange market are not fully centralized suggests that these systems do not represent a cost-minimizing arrangement.

\section{Structure of Prices}

The terms "double-auction" and "single-auction" refer to the nature of the prices quoted. In a double-auction market, certain participants provide prices on both sides of the market, that is, both bid and ask prices. Participants providing double-auction quotes upon demand are known as market-makers, and they must have sufficient capitalization to back up their quotes. In a singleauction market, prices are specified either to buy or to sell, but not both. In the foreign exchange market, market-makers provide double. auction prices, while brokers try to aggregate single-auction quotes into two-way (inside) spreads. A broker's book may occasionally be empty on one or both sides. Rather than make a market in such cases, the broker provides, respectively, a single-auction quote or none at all.

Thus, whether double or single-auction prices are quoted depends largely on whether the agent quoting prices is providing market-making services or simply attempting to acquire (or sell) the commodity. This issue is related to the degree of centralization in the market. The absence of market-makers in a single-auction market, together with the presence of search costs, results in a tendency toward centralization of price information, thus facilitating the search for a counterparty. Inversely, decentralization of price information leads to a tendency 
toward double-auction prices, again to facilitate the search for a counterparty.33

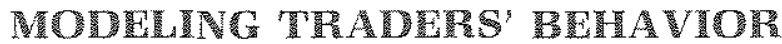

The microstructure literature extends well beyond a simple description of market institutions. Modeling the behavior of market participants is central to almost all discussions of microstructure. Although numerous approaches to such modeling have been taken, two common concerns are of special interest. These are the treatment of price information by market participants, and determination of the bid-ask spread. The latter raises the interrelated issues of inventory and quantity transacted.

\section{Price ERPectation}

Modeling the interpretation of price information is a crucial step in constructing microstructural models of price discovery. ${ }^{24}$ Many diverse approaches have been taken in such modeling. An almost universal simplification is to model securities markets in partial equilibrium, so that prices are not determined endogeneously in the traditional general equilibrium sense. This allows the modeler to focus on the microstructure's finer details. Another common simplification is to assume that agents ignore the impact of their own behavior on the market. ${ }^{25}$

Rather than explicitly model such forces as general equilibrium or recursive beliefs, models posit probability distributions that produce the prices of orders in the market. Modelers have included randomness at one or both of two levels, depending on their focus. First, order prices can be generated by objective distributions, that is, by stochastic processes exogenous

${ }^{23}$ Note that the converse does not appear to hold. That is, centratization does not tend to eliminate double-auction quoting. For example, the NASDAQ system on the OTC stock market centralizes price information while still supporting numerous market-makers for every stock.

${ }^{24}$ Notably, the term "price" is generally too inexact in a microstructural context. One must often distinguish at a minimum between quoted prices, transaction prices and equilibrium prices. There are also reservation prices, market-clearing prices and closing prices (see Schwartz (1988), chapter 9 , for the distinction between equilibrium and clearing prices). If unspecified here, the intended definition should be clear from the context.

25The atternative, which dates at least to Keynes' 'beauly contest," is recursive beliets, in which an agent considers the feedback of her own actions on the beliefs of others, and thence how the behavior on the other agents might affect her own beliefs, etc. See Keynes (1936), p. 156. The limiting case - an infinite recursion of beliefs-mpresumes to the market. For example, there may be a stochastic process that generates the "true" equilibrium price. Second, probability models of participants' subjective beliefs about prices can be used. Conroy and Winkler, for example, attribute subjective normal price distributions to market-makers, who use Bayesian updating to learn about the prices of incoming limit orders, ${ }^{26}$ Objective processes can coexist with subjective beliefs about those processes. Harsanyi suggests a consistency requirement for the subjective price distributions of multiple agents; these distributions are each equated with a conditional distribution of a single distribution known to all. ${ }^{27}$

Models can be further classified according to how they relate supply and demand. In particular, there are both models with single price processes and with dual price processes. In dual price models, purchase orders whether market or limit orders) are generated by one process, while sale orders are generated by another. ${ }^{2 s}$ The salient point here is that purchase and sale orders come from independent distributions. This independence is especially clear in Conroy and Winkler, where the distributional assumptions are explicit; there, independence implies that any sequence of buy orders, regardless of their prices and quantities, has no effect on the subjective probability of a sell order at any price.

Statistical independence implicitly restricts the ways in which orders can be generated. Purchase and sale orders are somehow motivated independently, although the cause of this separation is not always specified. Statistical independence is not a necessary component of a dual price process, however. Cohen, Maier, Schwart $z$ and Whitcomb (1981), for example, as. sume that actual market bid and ask prices are

extreme informational and comoutational resources on the part of agents, and models based on it are usually intractable. Intermediate approaches allowing a finite degree of recursion must somehow justify the truncation of recursive beliefs, just as the standard model of atomistic agents atlows no beliefs about beliefs and is justified by an assumption on the relative size of individual agents.

${ }^{26}$ See shaded insert on opposite page.

27See Harsanyi (1982), especially chapter 9 , and the references therem. His consistency requirement identifies a unique equilibrium for the game.

${ }^{28} \mathrm{~A}$ market order is an order to trade at the best price available; a limit order specifies a price. These models represent a strain of the literature that was pioneered by Demsetz using straightforward supply and demand schedules (see shaded insert on page 63). Similar approaches were later taken by Garman (1976), Amihud and Mendel. son (1980) and Conroy and Winkler (1981), among others. 


\section{Bayesian Learning of Price Information}

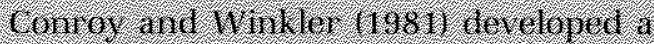

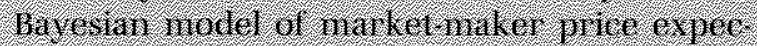
titions, Which is onllined fiere cinsider an expected profit maximaing monopdistic market-naker whol aces streams of hru and sell limit ordiers hom investors t . 11 orders are for a sngle round lot issune that the nirker-minker belieres that reservitior prices of buy orders, De are generated by a hormal distribution. $F,(1,4,0,1$, resemition prices of sell onder s. ID. are conerated hy a semond, in: dependent nomal distribution, $F,(n, \mu$. ol. That is. Whe namket maker has two nidepen. detif. normal, subjechve pice distribinions With corresponding densities, $f$, and 1 ], Mir ther issume that the narket-natker furmenty holds his desired imentory level. How should hiv set his spreart?

The inventory combition implies that the chosen bid and ask rates $B$ and 4 inust satisfs, the constraint, I. B) $=1$ - T, A1 so wat the expected thange in hiveniony is tero Gren his constratint, He expected prolit per

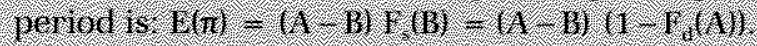
Maximizing his over $B$ and A vields: $B$ *

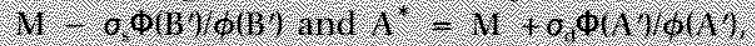

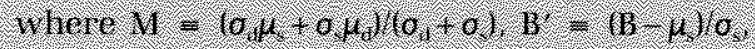
$A^{\prime}=(1-\mu) \sigma_{0}$, and $\phi(-)$ and $\phi()$ are the stan fard normal density and distribution fune tions. 1 can be shown that his aptimat

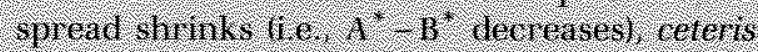
parhus as the subjective tariances 0 and 0 decrease:

The impontant aspeet of this stidy is that it provides an explicit mathenatical model for a market-naker's interpretation of price infor matur the narketmaker is assmed to behave in a Bayesian fashion, using the observed prices on heoming limit orders 10

Conoy and Whikel $(1981$ ) also consider a hisk averse narket naker and he intornation conveyed by a nar. t ket order which does nol specify a price. They do not incorporate the inpad of inentory on ptichg, nor do they generalize beyond the untealstid assuniption of normally distributed prices.

2 This is depeted in the lgure above. where price is on

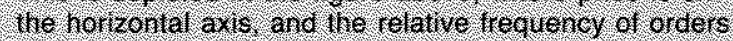
is on the veltical axis. The naketnake s spread ts

\section{Profit Per Pair of Trades and Expected Number of Trades Per Unit Time}

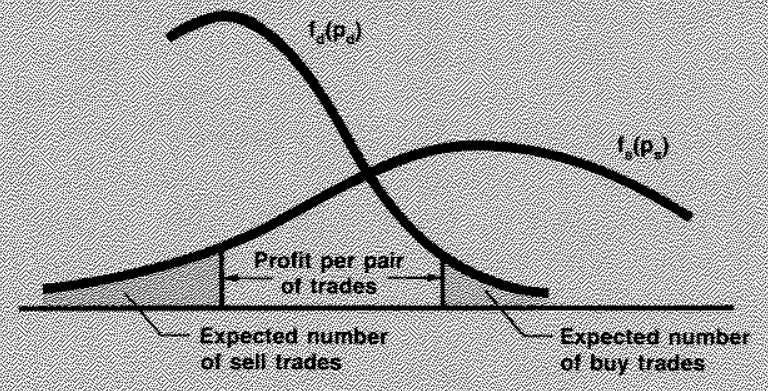

refine the parameters of his snbjective distrititions 100t example, assume that the market - maker vews pimchase pices as com

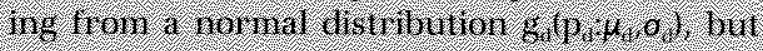
is unsure about the nean of lifis distidition Represent llis uncertanty ly a normal prior

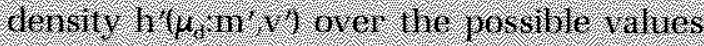
for the mean $\mu$, Given this the narginal subjectue clensilf over the prices of incoming limit orders, $f_{d}(p)=\int g,(p) t\left(\mu_{j}\right)$, is normal

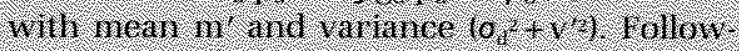
ing a sample of $n$ biy orders with nean price in the market maker is able to refine his subjective distribution of the nean. The

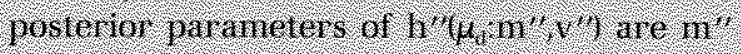

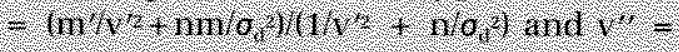

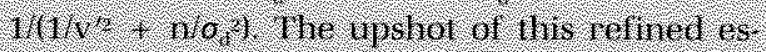
timate is that the variance of the margmal subjective price density, $f,(p)$, is now smaller. ind the market maker's optimal spread. (B*, $A^{*}$ ). is narrower:
The hiverval Irom B lo A and he mentory constrant is satisfied when the wo sh aded lalls have ecual area. Ther optinzation probien is sinilar h spitit to that of Alten $(1977)$ allhough the latter does nol consider learning 
independent Poisson processes and give investors joint subjective distributions over those prices. For the latter distributions, probabilistic independence of bid and ask prices is not explicitly required. Black (1989) models quantities (independent of prices) of market orders. Quantities supplied and demanded are drawn from different distributions, but the distributions are constrained to have the same mean. Garbade $(1978)_{\text {, }}$ on the other hand, assumes a single, unknown and fixed equilibrium price, around which market-makers set their spreads. Incoming buy and sell orders arrive via random processes whose mean arrival rates depend on the difference between the quoted bid (or ask) price and the exogenous equilibrium price and, thus, are not independent.

The most common alternative to separate purchase and sale processes is to model prices as some function of a single scalar process. This approach is in the spirit of the efficient markets literature, which posits a unique value for a security conditional on the available information. Ross (1987) points out that this approach can be regarded conceptually as a special case of the dual price process, with supply and demand infinitely elastic at a common price. Many authors reveal their theoretical roots by using terminology drawn from the literature on efficient markets. Thus, for example, Barnea describes a stock's "intrinsic value," which follows a random walk. ${ }^{29}$ Similarly, Copeland and Galai posit a "'true' underlying asset value ... known (ex ante) to all market participants. ${ }^{30}$ In contrast, Garbade's (1978) exogenous equilibrium price is unknown.

It is possible to extend the single price approach beyond the efficient markets tradition by modeling the value of a security subjectively rather than as an objective fact. Glosten and Milgrom (1985), for example, begin with an exogenous random value representing the consensus value of a stock given all public information. Investors do not act on this exogenous value directly; instead, they act on their expectation of it, conditional on their information set. Ho and Stoll personalize price expectations in a similar fashion: ${ }^{31}$
We take the dealer's opinion of the "true" price of the stock to be exogenously determined by his in. formation set and ask how the dealer prices relative to his "true" price...

This subjectivization of the pricing process is significant, because it allows for heterogeneous expectations and thus for more realistic modeling of price discovery.

Research into the microstructure of the foreign exchange market should presume such heterogeneity among market-makers. There are numerous market-makers for foreign exchange: The Federal Reserve Bank of New York (FRB-NY) (1989a) lists 162 dealing institutions in the U.S. interbank market. There would be little point in such superfluity if all market-makers were identical. Furthermore, it is well known that "taking a view," that is, speculating on future prices, is routine for many participants. ${ }^{32}$ To omit this heterogeneity from a model is to ignore an important characteristic of the market.

The large proportion of market-makers in the foreign exchange market has another important modeling implication. It implies that a singleprice process is more appropriate as a theoretical representation of agents' expectations. Market-makers consistently face other market-makers, who can hold positive or negative inventories of foreign currency with equal ease. A quote that is "off the market" on the high side will be hit (i.e., traded upon) just as surely as a quote that is off on the low side. This is also true of cus. tomers, who normally enter the market with a predilection to either buy or sell. As Burnham notes: ${ }^{33}$

The customer knows that if the first marketmaker is too far off the market price, he can unexpectedIy take the other side of the quote and resell the position to a second marketmaker.

The point is that the market-maker must expect to be penalized for underestimating as well as overestimating his counterparty's valuation of the currency. From the perspective of the market-maker, who quotes a spread and observes a response, the forces determining short-run ef. fective demand and supply are not merely related, but indistinguishable.
${ }^{29}$ See Barnea (1974), pp. 512-14.

30See Copeland and Galai (1983), p. 1458.

31 See Ho and Stoll (1981), p. 48. For a simitar example, see Stoll (1978), especially p. 1136 .
32See, for example, Kubarych (1983), p. 29, or Burnham

(1991), p. 139.

33See Burnham (1991), p. 136. 


\section{Dealer Services and the Bid-Ask Spread}

Iraditional wisdion refers to the bid ask spread as the fobber:s time : suggesting that it provides compensation to the dealer for the provision of services 1 Denset? (1968) formalized his rationale for the spread defining the particular senvice provided as : predictable in medicy and offering a simple model to destribe the spread.

Consider a conimumus narket with aggregate sipply 1 sell and demand fouy schedules s and 1 . for a secunity (see figure at righn. In an fdealized l vorld, investors would come logether simulianeously, and Whe narket would clear at price $\mathrm{p}^{*}$ and quanity $0^{*}$. In this nanket. place however such coordination of lrating is impossihle By assump. fion, the intrket is continuous, and there is tho nechanism fe g: a limit orider book lor holding orders over time: 1hus, 5 and $\mathrm{B}$ do not represen standard static stipply. and demand schedules, but rather lime rates of supjly and demand $\lambda \mathrm{t}$ aly given instant: there nay be no orders on either side.

Instead we introdice a monopelistic mar ket-naker who allows the Irading to occum lyy stanalig in as a counterparty 10 all traces. ho the process he provides a service to investors What Demsetz Tabels predictable immediacy. The narket maker lnows the aggregate stp: ply and demand propensifies the supply und demand curves that he presents to the public. St and $\mathrm{B}$. lowever, are both shifted leftward.

\section{Market Buy and Sell Curves with and Without the Provision of Immediacy}

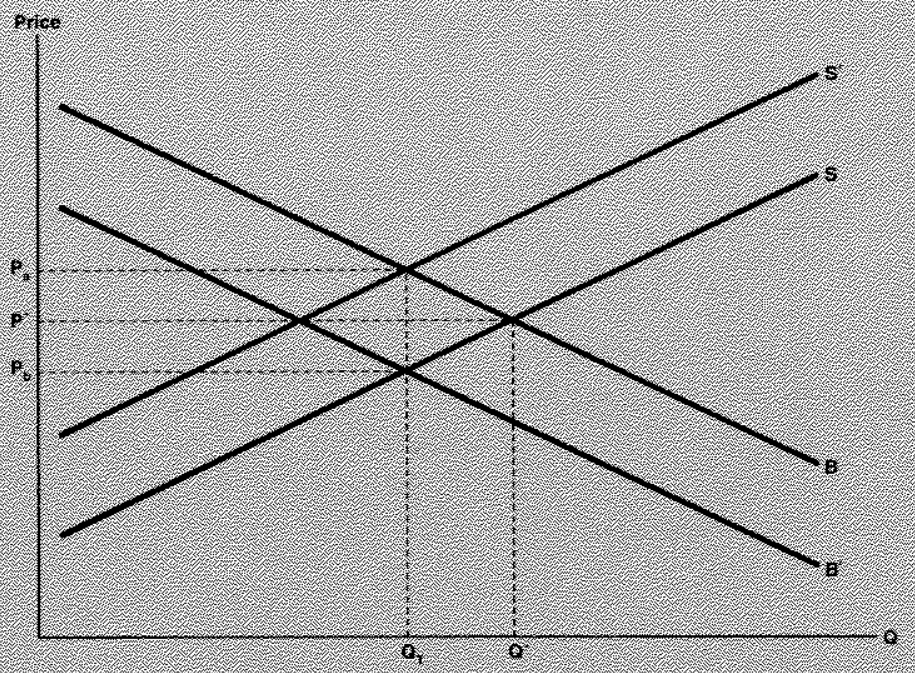

1See, tor example. keynes $(1936)$, o. 158 , or stigler

(1964). (1). 129

A market-maker's constant contact with other well-capitalized market-make's implies that this is not a theoretical fine point. In the words of one manket-maker; 34

Ninely percent of what we do is based on perception. It doesn't matter if that perception is right or investor pirchases dlear lor price $p$, at the intersection of the market demand schetule B, with the market-makers stuply sehedile. S. Similarly investor sales clear at he inter. section of $S$ and $\mathrm{U}$, for price $\mathrm{P}$. Whe differ ences: 1 . $P$ t and $P$ * $-p$, are liguidity premia Ii the figure, the quanities, 4 , purchiased and sold by the market maker happen to be equal, so that no mak et maker inveniory is accumulated His profit this equals $Q(\mathrm{p}-\mathrm{p}$ ) this is the 'jobber's turn:

${ }^{34}$ James Hohorst, as quoted by Mossberg (1988), p. $29 \mathrm{R}$. $\mathrm{Mr}$. Hohorst directed foreign exchange trading in North America for Manufacturers Hanover. 
perative of arbitrage avoidance must be regarded as the first priority in individual marketmaker pricing, to which all other factors (e.g., purchasing power parityl must be subordinated.

\section{Market-makers' Bid-Ask Spreads}

The bid-ask spread has attracted considerable interest in the literature on market microstructure. The complexity of modeling the spread is largely because it requires incorporating a substantial amount of institutional detail. At a facile theoretical level, a market-maker's spread appears to be a direct violation of the law of one price, since it assigns two prices to the same commodity, Several explanations have been offered to resolve this seeming inconsistency. They can be roughly categorized as involving the cost of dealer services, the cost of adverse selection and the cost of holding inventory. ${ }^{35}$

The dealer services argument can be traced back at least as far as Stigler (1964), who argues that stock exchange specialists charge a "jobber's turn" as compensation for the costs of acting as a specialist. The analysis of dealer services was formalized by Demsetz (1968), who identified "predictable immediacy" as the particular" service for which investors are willing to pay. This identification hints at the complex question of what liquidity is and where it comes from. In a busy market, liquidity is a public good: a continuous stream of buyers and sellers generates predictable immediacy as a by-product of their trading.

The determinants of the level of compensation are themselves a topic of debate. Stigler argues that, because centralization of exchange limits fixed costs and aggregates separate transaction orders into less risky actuarial order flows, it implies economies of scale and thus a natural monopoly for market-making. ${ }^{36}$ Smidt (1971) counters that barriers to entry among NYSE specialists allow them to exact monopoly rents from other investors. In his view, the natural monopoly argument, while used as an apology for barriers to entry, remains unsupported empirically: "There is no empirical evidence to support the proposition that [market-making] is, in fact, a natural monopoly. "3r Indeed, if market. making is a natural monopoly, barriers to entry should be unnecessary.

The foreign exchange market has no apparent barriers to entry other than the need for sufficient capitalization. It also has no apparent bar. riers to exit. The market supports a large and increasing number of competing market-makers. Unless it can be shown that there is some sub. tle restriction in the foreign exchange market that prevents consolidation of the market-making function, one must conclude that market-making per se is not a natural monopoly. ${ }^{38}$ The multitude of market-makers also implies that they cannot earn monopoly rents by embedding a premium for predictable immediacy in the spread, although the spread may still cover the costs of processing orders.

Other research suggests that a market-maker's job is more complex than the mere sale of counterparty services. A second explanation for the bid-ask spread - adverse selection - can be traced to Bagehot (1971). He starts with "liquidity-motivated transactors" who pay the market-maker the price of the spread in ex. change for the service of predictable immediacy. The market-maker also confronts traders who have inside information, however, and who can therefore speculate profitably at the expense of the market-maker. ${ }^{39}$ 'The market-maker must charge everyone a wider spread to compensate for losses to the information-motivated traders.

Because of the relatively abstract nature of currencies as commodities, it is difficult to construct examples of "inside" information on foreign exchange rates. One exception is money supply announcements, which, if known before

though the industry as a whole experiences economies of scale. Hamilton (1976) also addresses the natural monopoly question; Reinganum (1990) provides evidence on liquidity premia tor NYSE vS. NASDAQ stocks.

${ }^{39}$ This situation is called adverse selection, because, in a market with competing market-makers, the one who gets the insider's business is a loser rather than a winner. Bagehot also posits a third class of investors, who only think they have inside information; they speculate, but lose on average, and are indistinguishable to the market-maker from the liquidity-motivated traders. 
pablicly distributed, might provide a basis for profitable speculation. Another form of information that can be construed as inside information is knowledge of an arbitrage oppottunity. Consider a hypothetical market in which there are numerous decentralized market-makers who do not quote spreads, but single prices at which they are willing both to buy and sell. Unless there were a perfect consensus among the market-makers on the value of the foreign curvency, all of them would be vulnerable to arbitrage. $A$ decentralized market makes a perfect consensus difficult to achieve. Without centralizing price information, it is mpossible to know if no arbitrage opportunities exist. A bid-ask spread, in contrast, allows a market-maker to include an error tolerance in her prices, thus facilitating a price consensus; it is easier to get bid-ask spreads to overlap than to get scalar prices to coincide. The spread also provides the market-maker with some degree of protection from adverse selection in the form of arbitrage.

The bid-ask spread is also affected by inventory considerations. This idea dates back at least as far as Barnea and Logue (1975).40 The notion of a desired inventory level for the marketmaker underlies all of these models. In the simplest case, the desired level is set at zero, and a constant spread is shifted up and down on a price scale to equalize the probability of receiving a purchase order with that of receiving a sale order. The result is that the expected change in inventory is always equal to zero, and (with all trades for one round lot) the inventory level follows a simple random walk.

An undesirable implication of random-walk models of inventory is the inevitable bankruptcy of the market-maker. Finite capitalization levels for market-makers impose upper and lower bounds on allowable inventories. Because invenlory follows a random walk, with probability one it will reach either its upper or lower bound in a finite number of trades. ${ }^{41}$ The dymamic optimization models of Bradfield (1979), Amihud and Mendelson (1980) and Ho and Stoll (1981) resolve this problem. They conclude that a market-maker, optimizing his bid and ask prices

\footnotetext{
40.Barnea and Logue attribute it to Smidt (1971), although Smidt's paper does not explicilly develop the connection between the market-maker's inventory and his spread. For mal models of the relationship between inventories and spreads can be found in Sto:l (1978), Amihud and Mendelson (1980), Ho and Stoll (1981) and Sirri (1989), among others.

41 See, for example, Ross (1983), pp. 106-07.
}

over time in the face of a stochastic order flow, will shift both bid and ask rates downward (upwardl and increase the width of the spread when a positive (negative) inventory has accumulated. ${ }^{42}$

We should expect two of these three rationales for the spread to apply to market-makers' bid-ask spreads in the foreign exchange market. Because there are numerous market-makers, competition should eliminate their ability to earn monopoly rents by charging a premium for predictable immediacy per se. The adverse selection argument does apply in the foreign exchange market, however, since the spread allows market-makers some protection against arbitrage opportunities. Arbitrage opportunities can be construed as a form of inside information in a market where price information is not centralized. In accordance with the dynamic optimization models, a market-maker's inventory level should affect the spread, widening and shifting it as inventories accumulate.

\section{Broker's' Spreads}

So far, the discussion of the bid-ask spread has focused on models in which bid and ask prices are set by individual market-makers. The dual role of the stock exchange specialist suggests that this is only part of the story. Spreads are produced in two fundamentally different ways. It is only when limit orders are sparse that a NYSE specialist must step in as a marketmaker to provide an "orderly marke.." $W$ hen limit order volume is sufficient, the specialist acts as a broker, accounting for incoming limit orders on the limit order book, and pairing market orders against them. Cohen, Maier, Schwartz and Whitcomb (1979) note that inadequate attention has been given to the fact that not all prices are market-maker spreads. The market often makes itself without specialist assistance, through the aggregation of limit ordei's on the book

The foreign exchange market differs from the NXSE in that the market-making and brokerage roles are separated: market-makers do not act as brokers, and brokers do not make markets.

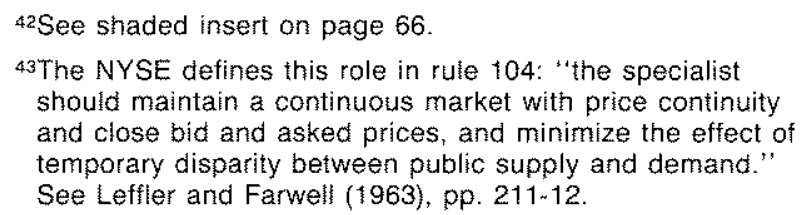
and close bid and asked prices, and minimize the effect of temporary dispatity between public supply and demand." See Leffler and Farwell (1963), pp. 211-12. 


\section{Dynamic Price-Inventory Adjustment Models}

Amilind and Nentelson (1580, 1982$)$ pro: Vile a niodel or narket-maker spread-seting That takes intentory into ocionint dssinime: That a market maket laces urder lows of bu and sell makket orders that arme according 10 independent poisson processes. The hav and sell arrival rales 6e. process intensiltest; d and s, respectively, depend on thi ask and bid prices, $\mathbf{P}$ and $\mathrm{p}$. Ihat the market-maker quotes $d$ - D $(P)$ and $s$ - S $(P)$ Denote the

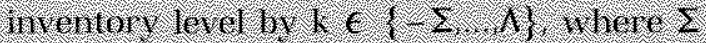
and $A$ are the largest allowable short and long positions respectively $1 \mathrm{et}$ d and s, de wote the order ar wal rates when prices are set as functims of the in eniory level. $d$.

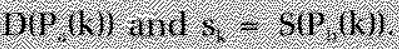

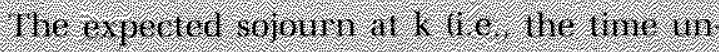
11 an andet hinves is giken hy lle porsson processes fuom as 1 (d, + , 1 . The probabinit

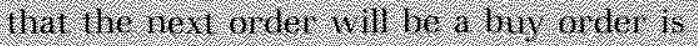

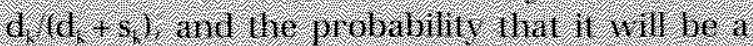
sell order is s. (d . s.). This the cxpected is sh llow jer unit ime at position $\mathrm{k}$ is given lov:

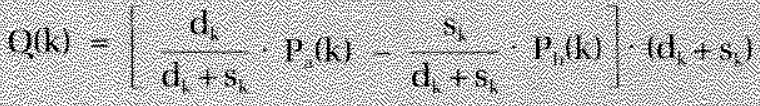

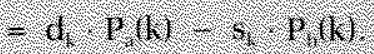

The maket maker s objectro is is naxminze. the expected proht per linit lime. gren hy

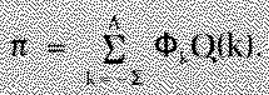

Where $\phi$ is the probability of heing at inven. tory level k. The solution to this optimization problem gives the values for $P(\mathrm{k})$ and $P_{\mathrm{f}}(\mathrm{k})$. Wich are depicted in the figure helow. The marketmaker comtrols inventory by adjusing prices up downt to nake an nvestor sale (jurehase) nore likely when inventory is low Thigh. The spread must widen as the invento: fy nears its homids in onder to avoid the inobten of a vandom walk lor inventoryt at the extremes: $d z=5,+0$.

\section{Optimal Prices and Bid-Ask Spread as a Function of Inventory Position}

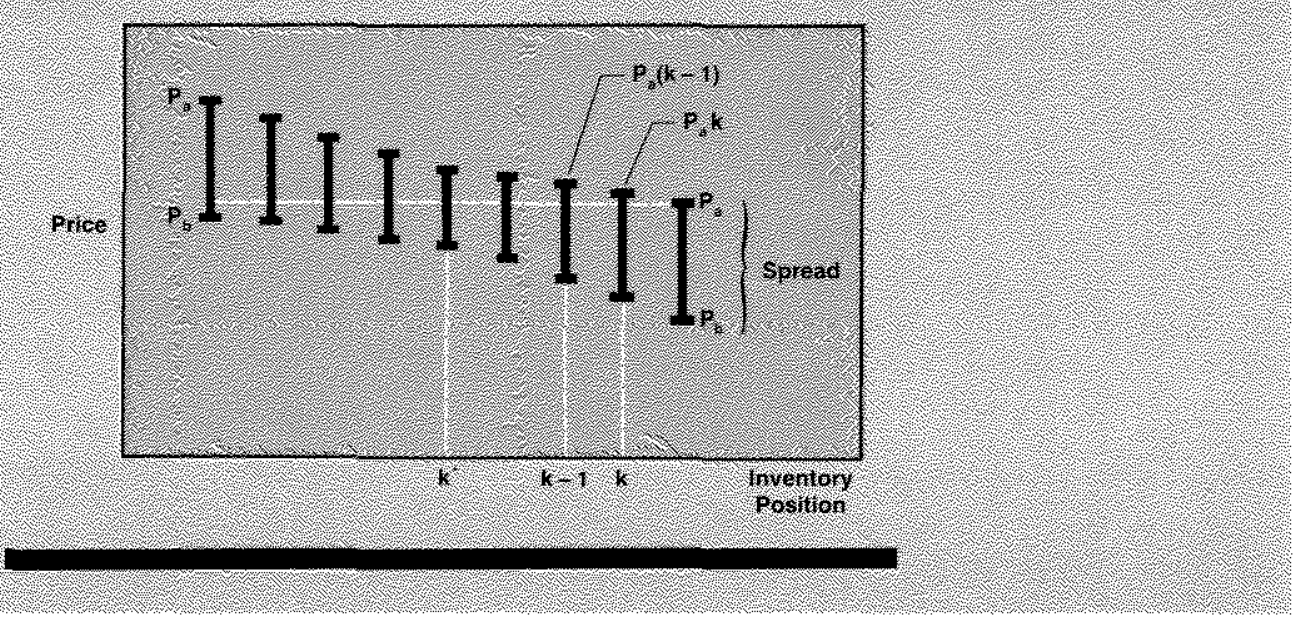

Therefore, it is even more appropriate to model brokered spreads as determined in a fundamentally different way from market-maker spreads. The separation of roles also has other implications for modeling foreign exchange brokerage.

A brokered spread is the combination of the best bid and best ask, received by the broker as separate limit orders. This arrangement might be modeled as a pair of extreme order statistics from independent distributions of purchase and sale limit orders. The distribution of these statisiics would have to be conditional on limit order volume and on the fact that the best ask must always exceed the best bid, since crossing ord- 
ers transact immediately and are removed from the book ${ }^{44}$ Perhaps because of its complexity, such a derivation has not been attempted.

Cohen, Maier, Schwartz and Whitcomb (1979) model limit orders as generated by "yawl" distributions. These distributions satisfy three heu. ristics for the incentives of investors placing limit orders. ${ }^{45}$ The heuristics are motivated by a notion of the centralized exchange as a market for immediacy; placers of limit orders produce immediacy, and placers of market orders consume it. This relationship between limit and market orders is formalized in Cohen, Maier, Schwartz and Whitcomb (1981), where each half of the brokered spread is assumed to be generated by a compound Poisson process. A minimum brokered spread results: if the limit order's bid (ask) price is sufficiently close to the specialist's ask (bid), the benefit to the investor of being able to specify the price of a limit order is overwhelmed by the cost of foregone immediacy.

Because models of the informational content of brokered spreads are few, the literature offers little guidance in modeling brokered quotes in the foreign exchange market. The yawl distribution is the only explicit distributional form for brokered spreads in the literature. Unfortunately, its heuristic basis cannot be transferred directly to the foreign exchange market, because market-makers there differ from stock market investors. Indeed, this may be an instance in which the foreign exchange market informs microstructure theory rather than the other way around. The extant approaches to brokerage treat it as a service facilitating predictable immediacy. This aspect of brokerage is redundant in the foreign exchange market, because of the multitude of marketmakers, each providing immediacy. This redundancy suggests instead that foreign exchange brokerage serves some other function.

One motive for trading through a foreign exchange broker is to maintain anonymity - the name of the bank placing a limit order is not revealed unless a deal is consummated and then only to the counterparty. ${ }^{46}$ Anonymity is valuable, because revealing a need to buy or sell a currency puts a market-maker at a bargaining disadvantage. In addition, anonymity can help pair market-makers who ordinarily would not contact each other directly. These issues have not been explored at a theoretical level. Until an adequate microstructural model of the strategic benefits of anonymity is developed, the theoretical understanding of foreign exchange brokerage will be limited.

\section{CONCLUSTONS}

Students of the foreign exchange market can draw several lessons from the literature on market microstructure. The most fundamental of these is that the institutional details of $e x$ change in a market can affect all aspects price, allocational, informational and operational - of the market's efficiency. A multitude of market-makers who can provide liquidity, or predictable immediacy, arises in response to the decentralization of the market. As a result, search costs are reduced relative to a world without market-makers, because finding one of many market-makers amounts to finding a counterparty. Brokerage also reduces search costs by achieving a degree of centralization in price information.

An unanswered question is why the specific combination of trading structures characteristic of the foreign exchange market - a decentralized, open-book, direct arrangement and a quasi-centralized, limit-book, brokered arrangement - should coexist. Apparently, each structure has relative advantages, but a full analysis of these advantages is lacking. Is there a single microstructure that would combine the relative advantages of the direct and brokered arrangements? Put another way, why does the microstructure of the foreign exchange market differ from that of the stock exchanges, the futures pits and the OTC stock market? Answering these questions will require a fuller specification of the objectives of a trading system and a better understanding of the impact of microstructural arrangements on those goals.

These issues provide a motive for deeper investigation of the behavior of the foreign ex-
A4An order statistic is defined as follows: the sample realizations of a finite number of independent zandom variables are ranked in increasing order, and the $k$ th order statistic is the kth number in that list. For the foreign exchange market, the modeling is still more complex, since brokers compare books amongst themselves in the sense that incoming orders can cross against any book.
45The yawl distribution, named for its resemblance to a sailboat, is a probability distribution contrived for modeling the generation of buy (or self) limit orders. See Cohen, Maier, Schwartz and Whitcomb $(1979,1983,1986)$ for details.

46See Kubarych (1983), p. 16, Burnham (1991), p. 141, and Federal Reserve Bank of New York (1989b), p. 41-3. 
change market and its participants. Marketmakers are the crucial element: they provide all transaction prices in the market and are involved in at least one side of every deal. The microstructure literature has developed numerous models of the interpretation and setting of prices by traders. The diversity of expectations models used in the literature illustrates the importance of tailoring such models to the specific environment confronted by market participants. Given that a foreign exchange market-maker's double-auction quote can be hit on either side (bid or ash) with equal ease, he must try to maneuver his spread to bracket the market's consensus valuation of the foreign currency. In other words, suppliers and demanders of cur. rency are indistinguishable to the market-maker ex ante. The inability to separate the forces determining effective demand from those determining effective supply in the very short run imply that a single-price expectations process (rather than a dual-price process) is appropriate in modeling market-makers in the foreign $e x$ change market.

A market-maker's bid-ask spread serves several purposes. Competition among market-makers in the foreign exchange market implies that they should be unable to charge a monopoly premium for the service of predictable immediacy. Instead, the spread obviates the need for perfect price consensus by giving the market-maker some protection from arbitrageurs with superior price information. While arbitrage avoidance must be considered a primary goal in setting a market-maker's bid and ask quotes, the spread provides flexibility elsewhere. Just as arbitmage avoidance is concerned with accurately estimating current prices, speculation is concerned with estimating future prices. By changing in size and shifting up or down, the spread can control stochastically the market-maker's foreign currency inventory in the face of random order flows. Systematic empirical study of the effect of inventories on market-makers' spreads is still needed, however.

The brokered spread is less well understood than the market-maker's spread, and certain areas are ripe for further research. Theoretical models of brokered spreads are few. The existing rationales for brokerage maintain that it provides liquidity services. In the foreign exchange market, however, numerous marketmakers make the liquidity services provided by brokerage superfluous. Descriptions of the for. eign exchange market suggest instead that anonymity is an important motive for trading in the brokered market. Yet the strategic value of anonymity in foreign exchange quoting is not well understood at a theoretical level. In addition, there is not a clear understanding of the differences in price information between a market-maker's spread and a broker's spread; this too remains a topic for future research.

From a broader perspective, a better understanding of institutional choice and change as regards securities market microstructure is necessary. Most microstructural research has been devoted to analyzing the impact of microstructural factors on important economic variables, such as price and allocation. Relatively little attention has been paid to the effect of economic factors on the choice of an institution. al microstructure.

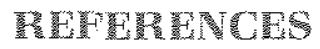

Alten, Wittam A. "A note on uncertainty, transaction costs and interest parity," Joumal of Monetary Economics (Juty 1977), pp. 36773.

Amihud, Yakov, Thomas S. Y. Ho, and Robert A. Schwartz, eds. Market Making and the Changing Structure of the Securities Industry, (Lexington Books, 1985).

Amhud, Yakov, and Haim Mendelson. "Dealership Market: Market-Making with Inventory," Joumal of Financial Economics (March 1980), pp. 31-53.

"Asset Price Behavior in a Dealership Market." Financial Analysts Journal (May/une 1982), pp. 50-59.

"Asset Pricing and the Bid-Ask Spread," Joumal of Financial Economics (December 1986), pp. 223-49.

"Liquidity and Asset Prices: Financial Management Implications." Financial Management (Spring 1988), pp. 5-15.

Bagehot, Walter. "The Only Game in Town," Financial Analysts Journal (March/Aprit 1971), pp. 12-14, 22.

Bank for International Settlements. "Survey of Foreign Exchange Market Activity." (February 1990).

Barnea, Amir. "Performance Evaluation of New York Stock Exchange Specialists," Joumal of Financial and Quantitative Analysis (September 1974), pp. 5tt-35.

Bamea, Amir, and Dennis E. Logue. "The Effect of Risk on the Market Maker's Spread," Financial Analysts Joumal (November/December 1975), pp. 45-49.

Beja, Avraham, and Nils H. Hakansson. "Dynamic Market Processes and the Rewards to Up-to-date Information," Journal of Finance (May 1977), pp. 291-304.

Benston, Geozge J., and Robert L. Hagerman. "Determinants of Bid-Asked Spreads in the Over-the-Counter Market," Journal of Financial Economics (1974), pp. 353-64.

Black, Stanley W. "Transaction Costs and Vehicle Currencies," IMF Working Paper WP189/96, International Monetary Fund (November 21, 1989). 
Bossaerts, Peter, and Pierre Hillion. "Market Microstructure Effects of Government Intervention in the Foreign Exchange Market," Review of Financial Studies (forthcoming).

Bradfield, James. "A Formal Dynamic Model of Market Making." Joumal of Financial and Quantitative Analysis (June 1979), pp. 275-91.

Brooks, J. A. "The dealing room and the dealer," in Rudi Weisweiller, ed., Managing a Foreign Exchange Department (Woodhead-Faukner, Cambridge, 1985), pp. 18-33.

Burnham, James B. "Current Structure and Recent Developments in Foreign Exchange Markets," in Sarkis J. Khoury, ed. Recent Developments in International Banking and Finance, Volume IV (Elsevier Science Publishers, Amsterdam, 1991), pp. 123-53.

Chrystal, K. Alec. "A Guide to Foreign Exchange Markets;" this Review (March 1984), pp. 5-18.

Cohen, Kalman J., Gabriet A. Hawawini, Steven F. Maier, Robert A. Schwartz, and David K. Whitcomb. "Implications of Microstructure Theory for Empirical Research on Stock Price Behavior" Journal of Finance (May 1980), pp. $249-57$.

Cohen, Kalman J., Steven F. Maier, Walter L. Ness, Jf., Hitoshi Okuda, Robert A. Schwariz, and David K. Whitcomb. "The impact of designated market makers on security prices." Journal of Banking and Finance (November 1977). pp. 219-47.

Cohen, Kalman d., Steven F. Maier, Robert A. Schwartz, and David K. Whitcomb. "The Returns Generation Process, Returns Variance, and the Effect of Thinness in Securities Makkets," Journal of Finance (March 1978a), pp. 149-67.

"Limit Orders, Market Structure, and the Returns Generation Process," Journal of Finance (June 1978b), pp. $723-36$

. "Market Makers and the Market Spread: A Review of Recent Literature," Joumal of Financial and Quantitative Analysis (November 1979), pp. 813-35.

"Transaction Costs, Order Placement Strategy, and Existence of the Bid-Ask Spread," Journal of Political Economy (April 1981), pp. 287-305.

"A simulation model of stock exchange trading." Simulation (1983), pp. 181-91.

The Microstructure of Securities Markets (PrenticeHall, Englewood Cliffs, 1986).

Cohen, Kalman J., and Pobert A. Schwartz. "An Electronic Call Market: Its Design and Desirability," in Henry C. Lucas, Jr. and Robert A. Schwartz, eds., The Challenge of information Technology for the Securifies Markets: Liquidity, Volatilty, and Global Trading (Dow Jones-Irwin, Homewood, 1989) pp. 20-58.

Conroy, Robert M., and Robert L. Winkler. "Informational Differences between Limit and Market Orders for a Market Maker:" Journal of Financial and Quantitative Analysis (December 1981), pp. 703-24.

Copeland, Thomas E. "A Model of Asset Trading under the Assumption of Sequential Information Arrival, "Journal of Finance (September 1976), pp. 1149-68.

Copeland, Thomas E., and Dan Gatai. "Intormation Effects on the Bid-Ask Spread", Journal of Finance (December 1983). pp. 1457-69.
Demsetz, Harold. "The Cost of Transacting." Quarterly Journal of Economics (February 1968), pp. 33-53.

Fama, Eugene F. Foundations of Finance (Basic Books, 1976).

Federal Reserve Bank of New York. "Summary of Results of U.S. Foreign Exchange Market Turnover Survey Conducted in April 1989," (September 13, 1989a). "The Foteign Exchange Committee: Annual Report 1988;" (June 1989b).

:Gross Foreign Exchange Transactions by Banks in U. S. Market Exceeds $\$ 23$ Billion Daily: Broker Tumover Separately Amounts to $\$ 8.5$ Billon Daily, New York Fed Survey Shows," (June 23, 1980).

Flood, Mark D. "Market Structure and Inefficiency in the For" eign Exchange Market," Working Paper 91-001A, Federal Reserve Bank of St. Louis (July 1991).

Garbade, Kenneth D. "The Effect of Interdealer Brokerage on the Transactional Characteristics of Dealer Markets;" Journal of Business (July 1978), pp. 477-98.

Garman, Mark B. "Market Microstructure," Journal of Financial Economics (June 1976), pp. 257-75

Glassman, Debra. "Exchange Rate Risk and Transaction Costs: Evidence from Bid - Ask Spreads," Jornal of international Money and Finance (December 1987), pp. 479-490.

Glosten, Lawrence A., and Paul R. Milgrom. "Bid, Ask and Transaction Prices in a Specialist Market with Heterogeneously Informed Traders" Journal of Financial Economics (March 1985), pp. 71-100.

Hahn, Frank H. Equilibrium and Macroeconomics, (Basil Blackwell, Oxford, 1984).

Hamilton, James L. "Competition, Scale Economies, and Transaction Cost in the Stock Market," Joumat of Financial and Quantitative Analysis (December 1976), pp. 779-802.

Harsanyi, John C. Papers in Game Theory, (D. Reidel, Dordrecht, 1982).

Ho, Thomas S. Y, and Richard G. Macris. "Dealer Market Structure and Performance" in Yakov Amihud, Thomas $S$. $Y$. Ho, and Robert A. Schwartz, eds, Market Making and the Changing Structure of the Securities industry (Lexington Books, Lexington, 1985), pp. 41-66.

Ho, Thomas S. Y, and Hans R. Stoll. "On Dealer Markets under Competition," Joumal of Finance (May 1980), pp. $259-68$.

"Optimal Dealer Pricing under Transactions and Fetum Uncertainty," Joumal of Financial Economics (March 1981), pp. $47-73$.

Keymes, John M. The General Theory of Employment, Interest and Money (MacMitan, London, 1936).

Kubarych, Foger M. Foreign Exchange Markets in the United States (Federal Reserve Bank of New York, 1983).

Leffler, George L., and Loring C. Farwell. The Stock Market, (Ronald Press, New York, 1963).

Logue, Denris E. "Market-Making and the Assessment of Market Efficiency." Journal of Finance (March 1975), pp. 115-23.

Lyons, Richard K. "Private Beliefs and Information Externalities in the Foreign Exchange Market," Working Paper, Columbia University (November 1991).

Mossberg. Walter $\mathrm{S}$ " Making Book on the Buck." Wall Street Joumal, September 23, 1988. 
Negishi, Takashi. "The Stability of a Competitive Economy: A Survey Article," Econometrica (October 1962), pp. 635-69.

Plott, Charles A. "Industrial Organization Theory And Exper. imental Economics," Joumal of Economic Literature (De cember 1982), pp. 1485-527.

"Witl Economics Become an Experimental Sci. ence?" Southern Economic Journal (April 1991). pp. 90\$-19.

Rai, Anoop K. "A Market Micro-Structure Investigation of Dealer Quotes and Pisk Premium in the Foreign Exchange Markets," Working Paper, (1991).

Reinganum, Marc R. "Market Microstructure and Asset Pricing: An empirical investigation of NYSE and NASDAQ securities," Journal of Financial Economics (Novemberl December 1990), pp. 127-47.

Riehl, Heinz, and Rita M. Rodriguez. Foreign Exchange and Money Markets: Managing Foreign and Domestic Currency Operations (McGraw-Hill, 1983).

Ross, Sheidon M. Stochastic Processes, (John Wiley \& Sons, 1983)

Ross, Stephen A. "The Current Status of the Capital Asset Pricing Model (CAPM)," Journal of Finance (June 1978), pp. 885-901.

\section{"The Interrelations of Finance and Economics}

Theoretical Perspectives." American Economic Review (May 1987), pp. 29-34.

Schreiber, Paut S., and Robert A. Schwartz. "Efficient Price Discovery in a Securities Marke: The Objective of a Trading System," in Yakov Amihud, Thomas S. Y. Ho, and Robert A. Schwartz, eds., Market Making and the Changing Structure of the Securities Industry (Lexington Books, Lexington, 1985), pp. 19.39.

"Price Discovery in Securities Markets," Joumal of Portfolio Management (Summer 1986), pp. 43-48.

Schwartz, Robert A. Equity Markets: Structure, Trading, and Performance (Harper \& Row, New York, 1988).
Sirri, Erik R. "Bid/Ask Spread, Price, and Volume in a Specialist Makket." Working Paper, University of California, Los Angeles (February 1989).

Smidt, Seymour. "Which Road to an Efficient Stock Market," Financial Analysts Journal (September/October 1971). pp. $18-20,64-69$.

Stigler, George J. "Public Regulation of the Secutities Markets," Journal of Business (April 1964), pp. 117.42 .

Stoll. Hans R. "The Supply of Dealer Services in Securities Markets," Joumal of Finance (September 1978) pp. $1133-51$

"Atternative Views of Market Making," in Yakov Amihud, Thomas S. Y. Ho, and Robert A. Schwartz, eds. Market Making and the Changing Structure of the Securifies Industry (Lexington Books, Lexington, 1985), pp. 67-91.

. "Inferring the Components of the Bid-Ask Spread Theory and Empirical Tests," Journal of Finance (March 1989), pp. 115-34.

Tinic, Seha M. "The Economics of Liquidity Services," Quar. terly Joumal of Economics (February 1972), pp. 79-93.

Tinic Seha M., and Richard R. West. "Competition and the Pricing of Dealer Service in the Over-the-Counter Stock Market," Journal of Financial and Quantitative Analysis (June 1972), pp. 1707-27.

Varian, Hal R. "Differences of Opinion in Financial Markets." in Courtenay C. Stone, ed., Financial Risk: Theory, Evidence and Implications (Kluwer Academic Publishers, Boston, 1989), pp. 3-37.

Wei, Shang-Jin. "Anticipations of Foreign Exchange Volatility and Bid - Ask Spreads," International Finance Discussion Paper No. 409. Board of Governors of The Federal Reserve System (August 1991).

Wolinsky, Ashe: "Information Revelation in a Market with Pairwise Meetings:" Econometrica (January 1990), pp. $1-23$ 